\title{
Interaksi Simbolik: Suatu Pengantar
}

\author{
Dadi Ahmadi
}

\begin{abstract}
Symbolic interaction focuses on 'interpretation' over subjective meaning derived from interaction of people with the others of his/her environment. As stated clearly in its name, symbolic interaction emphasized a close relationship — an exchange - between symbol and interaction. These exchanges produced special meanings and interpretations, unique for each person involved. Symbolic is derived from the word 'symbol' which means signs resulted from consensus. Symbolic Interaction tried to 'entering' meaning process and subject defining by employing participant observation to watch carefully how subject define themselves and their actions respectfully, based on definitions and meanings given by others in their environment.
\end{abstract}

Kata kunci: interaksi, simbol, interaksi simbolik, interpretasi

\section{Pendahuluan}

Awal perkembangan interaksi simbolik berasal dari dua aliran, Pertama, mahzab Chicago, yang dipelopori Herbert Blumer ${ }^{1}$ (1962), melanjutkan penelitian yang pernah dilakukan George Herbert Mead (1863-1931). Blumer meyakini bahwa studi manusia tidak bisa dilakukan dengan cara sama seperti penelitian pada benda mati. Seorang peneliti harus empati pada pokok materi, terjun langsung pada pengalamannya, dan berusaha untuk memahami nilai dari tiap orang. Blumer menghindari kuantitatif dan statistik dengan melakukan pendekatan ilmiah melalui riwayat hidup, otobiografi, studi kasus, buku harian, surat, dan nondirective interviews. Penekankan pentingnya ada pada pengamatan peneliti.

Lebih lanjutnya, tradisi Chicago melihat manusia sebagai kreatif, inovatif, dalam situasi yang tak dapat diramalkan. Masyarakat dan diri, dipandang sebagai proses, bukan sebagai struktur untuk membekukan proses atau menghilangkan intisari hubungan sosial. Kedua, mahzab Iowa yang mengambil lebih dari satu pendekatan ilmiah. Tokohnya adalah Manford Kuhn², salah satu karyanya adalah teknik pengukuran yang terkenal dengan sebutan Twenty Statement Self-Attitude Test (konsep pengujian sikap diri melalui dua puluh pertanyaan). Dua di antaranya adalah ordering variable, yaitu menyatakan kepentingan yang relatifmenonjol yang dimiliki individu dan locus variable, yaitu menyatakan perluasan tendensi yang secara umum dilakukan individu dalam mengindentifikasi kelompok konsensual.

Penilaian dari tes tersebut adalah dengan meletakkan pernyataan tersebut dalam dua kategori, konsensual dan subkonsensual. Pernyataan dianggap konsensual jika ia mengandung indentifikasi kelas atau golongan; sedangkan jika mengandung indentifikasi yang mengarah ke kualitas tertentu, maka ia merupakan pernyataan subkonsensual ${ }^{3}$. Kuhn berusaha 
mengembangkan konsep tentang diri (self) menjadi lebih konkret. Konsep yang lainnya tentang perencanaan tindakan (plan of action) yaitu pola tingkah laku seseorang terhadap objek, karena perencanaan diarahkan oleh sikap, yaitu pernyataan verbal yang menunjukkan nilai tujuan tindakan maka sikap dapat diukur. Konsep diri menyangkut perencanaan tindakan individu terhadap diri meliputi: identitas, kepentingan dan hal yang tidak disukai, tujuan, ideologi, dan evaluasi diri.

Interaksi simbolik telah menyatukan studi bagaimana kelompok mengkoordinasi tindakan mereka; bagaimana emosi dipahami dan dikendalikan; bagaimana kenyataan dibangun; bagaimana diri diciptakan; bagaimana struktur sosial besar dibentuk; dan bagaimana kebijakan publik dapat dipengaruhi yang merupakan sebuah gagasan dasar dari perkembangannya dan perluasan teorites Ilmu komunikasi.

\section{Akar Sejarah Teori Interaksi Simbolik: Sosiologi}

Komunikasi yang berlangsung dalam tatanan interpersonal tatap muka dialogis timbal balik dinamakan interaksi simbolik (Symbolic Interaction/SI). Kini, Interaksi simbolik telah menjadi istilah komunikasi dan sosiologi yang bersifat interdisipliner. Objek material (objectum material)nya pun sama, yaitu manusia, dan perilaku manusia (human behavior).

Interaksi adalah istilah dan garapan sosiologi; sedangkan simbolik adalah garapan komunikologi atau ilmu komunikasi. Kontribusi utama sosiologi pada perkembangan ilmu psikologi sosial yang melahirkan perspektif interaksi simbolik. Perkembangan ini bisa dikaitkan dengan aliran Chicago. Perkembangan sosiologi di Amerika sejauh ini didahului oleh penyerapan akar sosiologi yang berkembang luas di Eropa.

Untuk memahami fenomena masyarakat, menurut Blumer, se-orang peneliti harus melakukan observasi secara langsung atau partisipatif dengan dua cara, yaitu (1) eksplorasi ke tingkat pemahaman yang meng-hasilkan sensitivizing concepts. Peneliti di-harapkan bisa dekat dengan objek/ subjeknya agar mampu mengenali dan memahami konteks empiris yang sebenarnya; (2) melakukan inspeksi, di mana peneliti harus me-meriksa data dengan cara menampilkan pembukti-an empirisnya.

Joel M Charron (1979) berpendapat pentingnya pe-mahaman terhadap simbol ketika peneliti menggunakan teori interaksi simbolik. Simbol adalah objek sosial dalam interaksi yang digunakan sebagai perwakilan dan komunikasi yang ditentukan oleh orang-orang yang menggunakannya. Orang-orang tersebut memberi arti, menciptakan dan mengubah objek di dalam interaksi. Simbol sosial tersebut dapat mewujud dalam bentuk objek fisik (benda kasat mata), katakata (untuk mewakili objek fisik, perasaan, ide dan nilai), serta tindakan (yang dilakukan orang untuk memberi arti dalam ber-komunikasi dengan orang lain).

Dalam Sosiologi, banyak sekali teori dan perspektif. Ada yang meng-gunakan perspektif evolusionisme, interaksionisme, fungsionalisme, teori konflik, pertukaran, dan ada juga yang menggunakan pembagian dalam pandangan George Ritzer, ${ }^{4}$ yakni fakta sosial, definisi sosial, dan peri-laku sosial. Semua pendekatan memiliki karakteristik dan tujuan yang berbeda-beda dalam rangka meng-analisis masyarakat.

Salah satu teori sosiologi yang cukup berpengaruh adalah Interaksi Simbolik yang fokus pada perilaku peran, interaksi antarindividu, serta tindakan-tindakan dan komunikasi yang dapat diamati. Melalui pendekatan ini, secara lebih spesifik, peneliti dapat menguraikan perkembangan sejarahnya dan man-faatnya bagi individu maupun masyarakat itu sendiri.

Berdasarkan apa yang menjadi dasar dari kehidupan kelompok manusia atau masyarakat, beberapa ahli dari paham Interaksi Simbolik menunjuk pada "komunikasi" atau secara lebih khusus "simbol-simbol" sebagai kunci untuk memahami kehidupan manusia itu. Interaksi Simbolik menunjuk pada sifat khas dari interaksi antarmanusia. Artinya manusia saling menerjemahkan dan mendefinisikan tindakannya, baik dalam interaksi dengan orang lain maupun 
Gambar 1

Proses Interaksi dalam Masyarakat

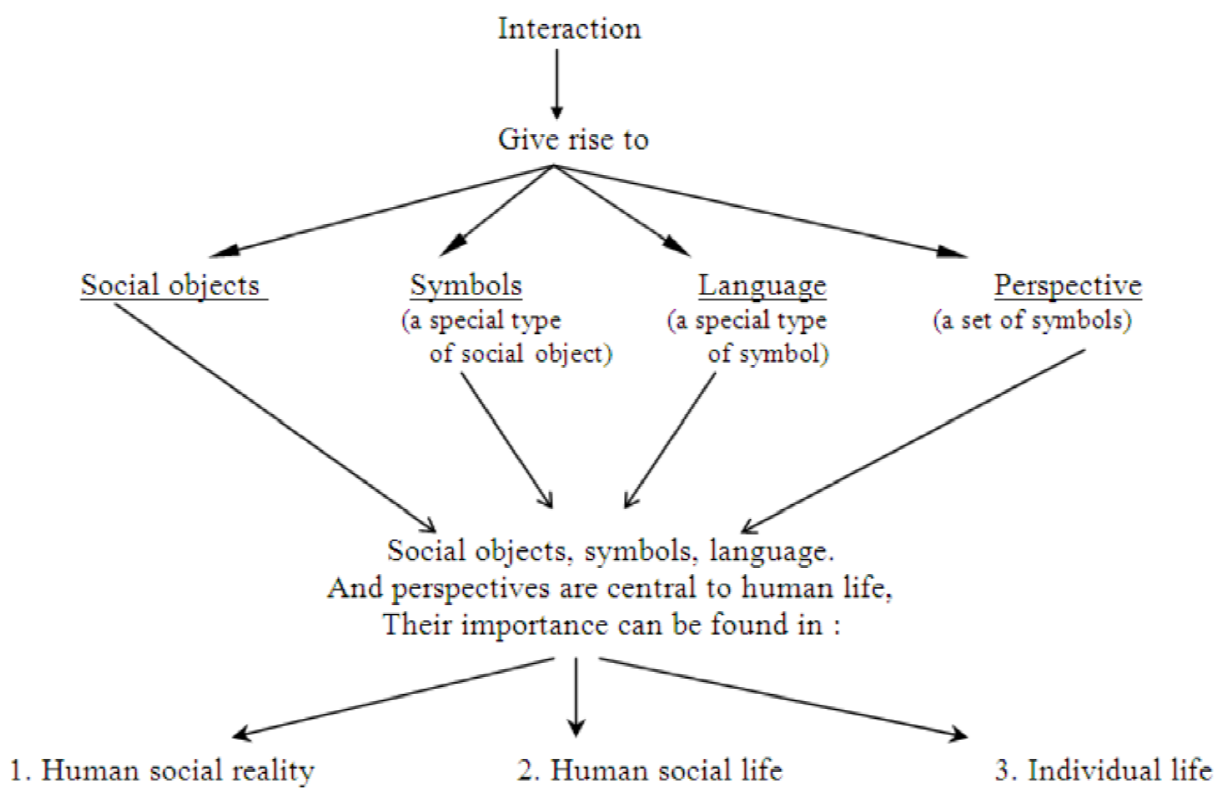

Sumber: Charon, 1979:61

dengan dirinya sendiri. Proses interaksi yang terbentuk melibatkan pemakaian simbol-simbol bahasa, ketentuan adat istiadat, agama dan pandangan-pandangan. Menurut Joel Charon proses Interaksi Simbolik yang terbentuk dalam suatu masyarakat bisa dilihat pada gambar di atas.

Pada gambar 1, memerlihatkan bahwa pola interaksi terbentuk secara simbolik meliputi bahasa, objek sosial, lambang-lambang, dan berbagai pandangan. Blumer (dalam Veeger, 1993:224-227) mengembangkan lebih lanjut gagasan Mead dengan mengatakan bahwa ada lima konsep dasar dalam interaksi simbolik, yaitu Pertama, konsep diri (self), memandang manusia bukan semata-mata organisme yang bergerak di bawah pengaruh stimulus, baik dari luar maupun dari dalam, melainkan "organisme yang sadar akan dirinya" (an organism having a self). Ia mampu memandang diri sebagai objek pikirannya dan bergaul atau berinteraksi dengan diri sendiri.

Kedua, konsep perbuatan (action), karena perbuatan manusia dibentuk dalam dan melalui proses interaksi dengan diri sendiri, maka perbuatan itu berlainan sama sekali dengan gerak makhluk selain manusia. Manusia menghadapi berbagai persoalan kehidupannya dengan beranggapan bahwa ia tidak dikendalikan oleh situasi, melainkan merasa diri di atasnya. Manusia kemudian merancang perbuatannya. Perbuatan manusia itu tidak semata-mata sebagai reaksi biologis, melainkan hasil konstruksinya.

Ketiga, konsep objek (object), memandang manusia hidup di tengah-tengah objek. Objek itu dapat bersifat fisik seperti kursi, atau khayalan, 
kebendaan atau abstrak seperti konsep kebebasan, atau agak kabur seperti ajaran filsafat. Inti dari objek itu tidak ditentukan oleh ciri-ciri instrinsiknya, melainkan oleh minat orang dan arti yang dikenakan kepada objek-objek itu.

Keempat, konsep interaksi sosial (social interaction), interaksi berarti bahwa setiap peserta masing-masing memindahkan diri mereka secara mental ke dalam posisi orang lain. Dengan berbuat demikian, manusia mencoba memahami maksud aksi yang dilakukan oleh orang lain, sehingga interaksi dan komunikasi dimungkinkan terjadi. Interaksi itu tidak hanya berlangsung melalui gerakgerik saja, melainkan terutama melalui simbolsimbol yang perlu dipahami dan dimengerti maknanya. Dalam interaksi simbolik, orang mengartikan dan menafsirkan gerak-gerik orang lain dan bertindak sesuai dengan makna itu.

Kelima, konsep tindakan bersama (joint action), artinya aksi kolektif yang lahir dari perbuatan masing-masing peserta kemudian dicocokan dan disesuaikan satu sama lain. Inti dari konsep ini adalah penyerasian dan peleburan banyaknya arti, tujuan, pikiran dan sikap.

Oleh karena itu, interaksi sosial memerlukan banyak waktu untuk mencapai keserasian dan peleburan. Eratnya kaitan antara aktivitas kehidupan manusia dengan simbol-simbol karena memang kehidupan manusia salah satunya berada dalam lingkungan simbolik.

Kaitan antara simbol dengan komunikasi terdapat dalam salah satu dari prinsip-prinsip komunikasi yang dikemukakan Mulyana (2000:83120) mengenai komunikasi adalah suatu proses simbolik. Lambang atau simbol adalah sesuatu yang digunakan untuk menunjuk sesuatu lainnya, berdasarkan kesepakatan sekelompok orang. Lambang meliputi kata-kata (pesan verbal), perilaku nonverbal, dan objek yang maknanya disepakati bersama. Lambang adalah salah satu kategori tanda. Hubungan antara tanda dengan objek dapat juga direpresentasikan oleh ikon dan indeks, namun ikon dan indeks tidak memerlukan kesepakatan. Ikon adalah suatu benda fisik (dua atau tiga dimensi) yang menyerupai apa yang direpresentasikannya. Representasi ini ditandai dengan kemiripan. Berbeda dengan ikon, indeks atau dikenal dengan istilah sinyal, adalah suatu tanda yang secara alamiah merepresentasikan objek lainnya. Pemahaman tentang simbol-simbol dalam suatu proses komunikasi merupakan suatu hal yang sangat penting, karena menyebabkan komunikasi itu berlangsung efektif.

\section{Tokoh dan Perkembangan Interaksi Simbolik}

George Herbert Mead adalah tokoh yang tidak bisa lepaskan dari teori Interaksi Simbolik. Dia adalah pengajar filsafat---dan bukannya sosiologi-di Universitas Chicago dari 1863-1931 5. Akan tetapi, banyak mahasiswa sosiologi yang mengambil kuliahnya. Para mahasiswa itulah yang kemudian membukukan "tradisi oral"-nya Mead me-ngenai interaksi simbolik menjadi tertulis, sehingga catatan kuliah mereka dari Mead digunakan sebagai basis karya yang di kemudian hari terkenal dengan, Mind, Self and Society: From the Standingpoint of a Social Behav-iorist. Ada dua akar intelektual paling signifikan dari karya Mead pada khususnya, dan mengenai Interaksi Simbolik pada umumnya, yakni filsafat pragmatisme dan behaviorisme psikologis. Sedangkan masukan penting yang lainnya lagi dari teori ini berasal dari George Simmel ${ }^{6}$, khususnya gagasan-gagasannya mengenai konsep interaksi.

Charon (1985) mengatakan bahwa pragmatisme adalah sebuah pe-mikiran filosofis yang berjangkauan luas, yang dari pe-mikiran tersebut kita bisa mengidentifikasi beberapa aspek yang memengaruhi orientasi sosiologis Mead yang sedang berkembang. Pertama, buat para penganut aliran pragmatis realitas yang benar tidaklah eksis "di luar sana", di dunia yang riil. Realitas tersebut sebenar-nya "tercipta secara aktif saat kita bertindak dalam dan menuju dunia". Kedua, sebenarnya individu akan mengingat dan mendasarkan pengetahuan mereka mengenai dunia yang telah terbukti berguna buat mereka. Mereka cenderung mengubah apa yang tidak lagi "berguna." Ketiga, individu mendefinisikan, "objek" sosial dan fisik yang mereka jumpai di dunia sesuai dengan gunanya bagi mereka. 
Terakreditasi Dirjen Dikti SK No. 56/DIKTI/Kep/2005

Akhirnya, jika kita ingin me-mahami seorang pelaku, maka kita semestinya men-dasarkan pemahaman itu pada apa yang mereka laku-kan.

Tiga hal yang sangat penting mengenai konstruksi teori Interaksi Simbolik, adalah (1) Fokus pada interaksi antara pelaku dan dunia; (2) Pandangan bahwa baik pelaku maupun dunia sebagai proses yang dinamis dan bukanlah struktur yang statis; dan (3) Nilai yang dilekatkan pada kemampuan pelaku untuk menginterpretasikan dunia atau masyarakat sosial.

Dalam karya filsuf pragmatis yang terkenal, yakni John Dewey pernah mengatakan tidak memandang pikiran (mind) sebagai suatu benda (a thing) atau sebuah struktur, namun lebih sebagai suatu proses berpikir yang melibat-kan serentetan tahap. Tahap itu, meliputi pen-definisian objek dalam dunia sosial, mensketsakan modus tindakan yang mungkin, mengimajinasikan konsekuensi dari tindakan alternatif, mengeliminasi sesuatu yang cenderung kurang mungkin, dan akhirnya menyeleksi modus tindakan yang optimal. Fokus atas proses berpikir ini ber-pengaruh luar biasa dalam perkembangan Interaksi Simbolik.

David Lewis dan Richard Smith ber-pendapat bahwa Dewey (dan William James) tampak lebih berpengaruh dalam perkembangan Interaksi Simbolik ketimbang Mead. Mereka bergerak lebih jauh dengan mengatakan bahwa, "Karya Mead lebih ber-sifat periferal saja dibandingkan arus utama sosiologi Aliran Chicago". Dengan pendapat seperti ini, mereka membedakan antara dua cabang pragmatisme yang utama, yaitu "realisme filosofis" (philosophical realism) yang dikaitkan dengan Mead - dan "pragmatisme nominalis" (nominalist prag-matism) —yang dikaitkan dengan Dewey dan James). — ${ }^{77}$

Sebenarnya, dalam pandangan mereka, Interaksi Simbolik lebih dipengaruhi oleh pendekatan nominalis dan bahkan tidak konsisten dengan realisme filosofis. Pemikiran nominalis adalah bahwa meskipun fenomena level-makro itu ada, mereka tidak memiliki "efek yang independen dan menentukan atas kesadaran dan atas perilaku individu". Lebih tepatnya lagi, pandangan itu, "Memahami indi-vidu sendiri sebagai agen yang secara eksistensi bebas yang bisa menerima, menolak, memodifikasi, atau sebaliknya, 'menegaskan' norma, peran, kepercayaan masyarakat, dan sebagainya, sesuai dengan kepentingan dan rencana mereka sendiri pada waktu itu". Sebaliknya, dalam pandangan realisme sosial, lebih menekankan pada masyarakat dan bagai-mana itu bisa membentuk dan mengendalikan proses mental individu. Lebih tepatnya mungkin sebagai agen bebas; para pelaku sadar bahwa perilaku mereka di-kendalikan oleh komunitas yang lebih luas.

Tokoh-tokoh yang beraliran interaksi simbolik sebagaimana yang disebut di atas, seperti: Wiliam James, James M. Baldwin, John Dewey, George H. Mead, yang kemudian dilanjutkan oleh Charles Horton Cooley, Wiliam I. Thomas, dan Kuhn maupun Herbert Blumer. Para tokoh ini sepakat menggunakan nama interaksi simbolik untuk menjelaskan suatu tindakan bersama, pada saatnya nanti akan membentuk struktur sosial atau kelompok-kelompok masyarakat lain melalui interaksi yang khas. Teori interaksi simbolik mengasumsikan bahwa individu-individu melalui aksi dan interaksinya yang komunikatif, dengan memanfaatkan simbol-simbol bahasa serta isyarat lainnya-yang akan mengonstruk masyarakatnya, (Soeprapto, 2002).

Teori ini mewarisi tradisi dan posisi intelektual yang berkembang di Eropa pada abad 19 kemudian menyeberang ke Amerika, terutama di Chicago. Namun, sebagian pakar berpendapat, teori interaksi simbolik khususnya G.H. Mead (1920-1930-an), terlebih dahulu dikenal dalam lingkup sosiologi interpretatif yang berada di bawah payung teori tindakan sosial (action theory), yang dikemukakan oleh filsuf sekaligus sosiolog besar Max Weber (1864-1920) (Basrowi dan Sukidin, 2002:111).

Interaksi simbolik berinduk pada perspektif fenomenologis. Istilah fenomenologis, menurut Natanson, merupakan satu istilah generik yang merujuk pada semua pandangan ilmu sosial yang menganggap kesadaran manusia dan makna objektifnya sebagai titik sentral untuk memeroleh pengertian atas tindakan manusia dalam sosial masyarakat. Pada tahun 1950-an dan 1960-an 
perspektif fenomenologis mengalami kemunduran. Surutnya perspektif fenomenologis memberi kemungkinan bagi para ilmuwan untuk memunculkan teori baru dalam bidang ilmu sosial. Kemudian, muncullah teori interaksi simbolik yang mendapat tempat utama dan mengalami perkembangan pesat hingga saat ini. Max Weber adalah orang yang turut berjasa besar dalam memunculkan teori interaksi simbolik. Ia pertama kali mendefinisikan tindakan sosial sebagai sebuah perilaku manusia pada saat person memberikan suatu makna subjektif terhadap perilaku yang ada. Sebuah tindakan bermakna sosial manakala tindakan tersebut timbul dan berasal dari kesadaran subjektif dan mengandung makna intersubjektif.
Artinya terkait dengan orang di luar dirinya.

Meskipun teori interaksi simbolik tidak sepenuhnya mengadopsi teori Weber, namun pengaruh Weber cukup penting. Salah satu pandangan Weber yang dianggap relevan dengan pemikiran Mead adalah tindakan sosial bermakna jauh, berdasarkan makna subjektifnya yang diberikan individu-individu, tindakan itu memertimbangkan perilaku orang lain dan kerenanya diorientasikan dalam penampilan (Mulyana, 2006). Dalam perkembangan selanjutnya, teori Interaksi Simbolik ini dipengaruhi beberapa aliran, di antaranya Mazhab Chicago, Mazhab Iowa, pendekatan Dramaturgis dan Etnometodologi yang diilhami pandangan filsafat,

Gambar 2

Perkembangan Interaksi Simbolik

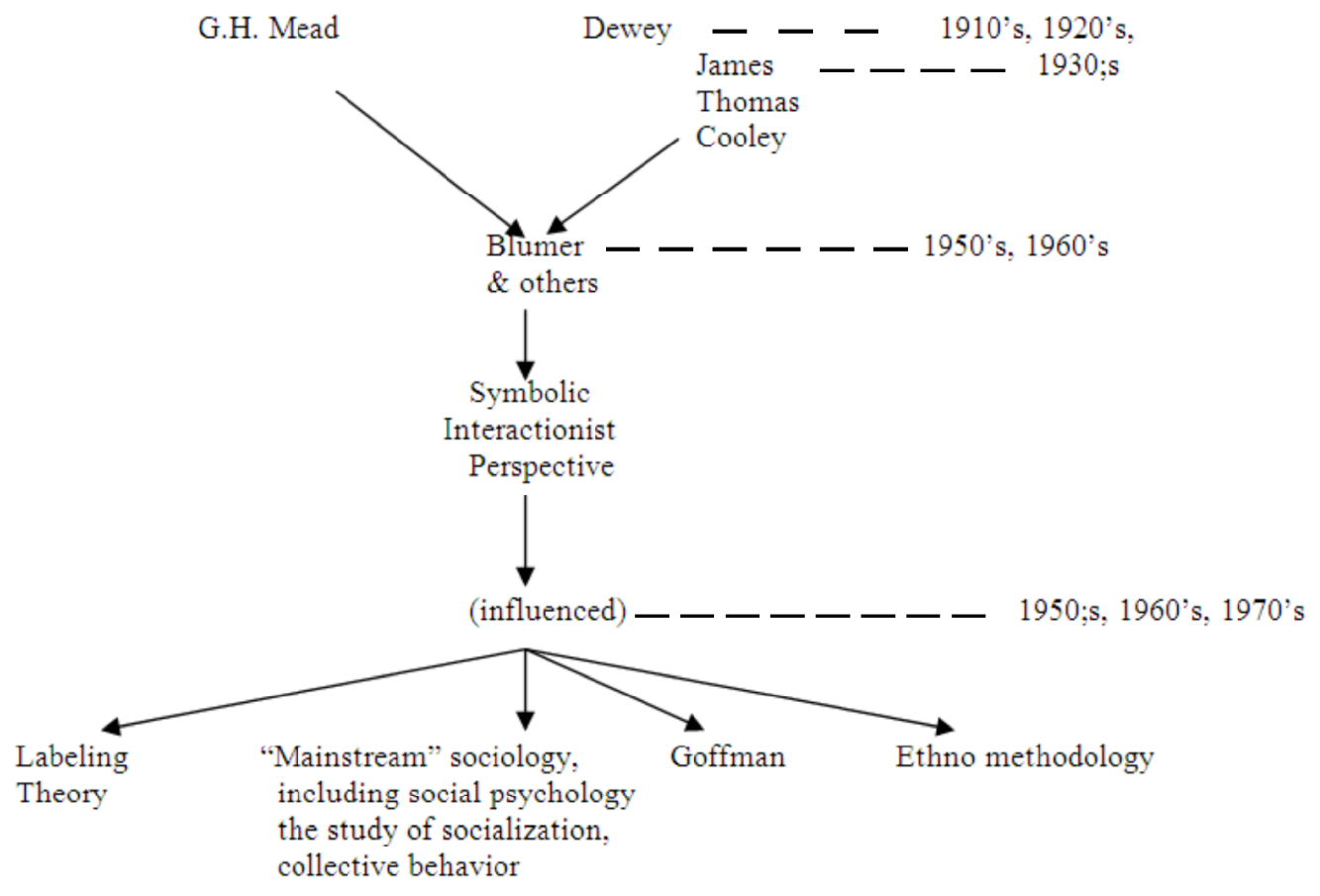

Sumber: Basrowi dan Sukidin, 2002:111 
Terakreditasi Dirjen Dikti SK No. 56/DIKTI/Kep/2005

khususnya pragmatisme dan behaviorisme. Interaksi simbolik juga menginspirasi konsep labeling dan pendekatan dramaturgisnya Erving Goffman. Charon menggambarkan perkembangan interaksi simbolik, sebagaimana pada Gambar 2.

Aliran pragmatisme yang dirumuskan John Dewey, Wiliam James, Charles Peirce, dan Josiah Royce mempunyai beberapa pandangan: pertama, realitas sejati tidak pernah ada didunia nyata, melainkan secara aktif diciptakan ketika kita bertindak terhadap dunia. Kedua, manusia mengingat dan melandaskan pengetahuan mereka tentang dunia pada apa yang terbukti berguna bagi mereka. Ketiga, manusia mendefinisikan objek fisik dan objek sosial yang mereka temui berdasarkan kegunaannya bagi mereka, termasuk tujuan mereka. Keempat, bila kita ingin memahami orang yang melakukan tindakan (actor), kita harus berdasarkan pemahaman itu pada apa yang sebenarnya mereka lakukan di dunia. Sementara, aliran behaviorisme yang dipelopori Watson berpendapat bahwa manusia harus dipahami berdasarkan apa yang mereka lakukan (Mulyana, 2006: 64).

Hal tersebut dimaksudkan tidak untuk mempertentangkan wilayah subtsansi kajian, tetapi hanya sebatas deskripsi kajian teori interaksi simbolik, sebagai salah satu pendekatan alternatif dari sekian banyak teori sosial untuk memahami individu dan masyarakat. Untuk lebih memudahkan pemahaman inti dan lingkup kajian teori interaksi simbolik, berikut beberapa tokoh dan konsepnya.

\subsection{Konsep “diri” dari George Herbert Mead"}

Tokoh ilmuwan yang memiliki andil utama sebagai perintis Interaksi Simbolik adalah G. Herbert Mead. Gagasannya mengenai interaksi simbolik berkembang dan mengalir dalam bukunya Mind, Self, and Society (1934), yang menjadi rujukan teori Interaksi Simbolik. Menurutnya, inti dari teori interaksi simbolik adalah tentang "diri" (self), menganggap bahwa konsepsi-diri adalah suatu proses yang berasal dari interaksi sosial individu dengan orang lain. Bagi Mead, individu adalah makhluk yang bersifat sensitif, aktif, kreatif, dan inovatif. Keberadaan sosialnya sangat menentukan bentuk lingkungan sosialnya dan dirinya sendiri secara efektif (Soeprapto, 2002). Lebih jauh, Mead menjelaskan bahwa konsep "diri" (self) dapat bersifat sebagai objek maupun subjek sekaligus. Objek yang dimaksud berlaku pada dirinya sendiri sebagai karakter dasar dari makhluk lain, sehingga mampu mencapai kesadaran diri (self conciousness), dan dasar mengambil sikap untuk dirinya, juga untuk situasi sosial. Argumentasi Mead dijabarkan dengan konsep "pengambilan peran orang lain" (taking the role of the other,) —sebagai penjelasan "diri sosial" (social self) dari William James, dan pengembangan teori "diri" dari Cooley-. Menurutnya, "diri" akan menjadi objek terlebih dahulu sebelum ia berada pada posisi subjek. Dalam hal ini, "diri akan mengalami proses internalisasi atau interpretasi subjek, atas realitas struktur yang luas. Dia merupakan produk dialektis dari " $\Gamma$ " impulsive dari "diri", yaitu aku, sebagai subjek dan "Me" sisi sosial dari manusia yaitu "daku" sebagai objek, Perkembangan "diri" (self), sejalan dengan sosialisasi individu dalam masyarakat yakni merujuk kepada kapasitas dan pengalaman manusia sebagai objek bagi diri sendiri. Ringkasnya, argumen Mead, bahwa "diri” muncul dalam proses interaksi karena manusia baru menyadari dirinya sendiri dalam interaksi sosial.

\subsection{Charles Horton Cooley tentang "Diri" 9}

Adalah tokoh yang penting dalam perkembangan Interaksi simbolik ini berusaha mendapatkan pemahaman yang lebih dalam mengenai individu, namun bukan sebagai entitas yang terpisah dari masyarakat. Cooley mendefinisikan "diri” sebagai segala sesuatu yang dirujuk dalam pembicaran biasa melalui kata ganti orang pertama tunggal. Cooley berpendapat bahwa "aku” (I), "daku”, (me), "milikku”, (mine), dan "diriku" (my self). Menurutnya, segala sesuatu yang dikaitkan dengan diri menciptakan emosi lebih kuat dibandingkan dengan yang tidak dikaitkan dengan diri bahwa diri dapat dikenal hanya melalui perasaan subjektif. Dalam teorinya the lookingglass self, Cooley berargumen bahwa konsep diri individu secara signifikan ditentukan apa yang ia pikirkan tentang pikiran orang lain mengenai 
dirinya. Artinya, individu memerlukan respons orang lain yang ditafsirkan subjektif sebagai data dirinya, (Mulyana, 2006). Anggapannya bahwa perasaan "diri" dikembangkan lewat penafsiran individu atas realitas fisik dan sosial, termasuk aspek-aspek pendapat tentang tubuh, tujuan, materi, ambisi, gagasan bersifat sosial yang dianggap milik individu. Lebih jauh, Cooley menjelaskan bahwa perasaan diri bersifat sosial karena maknanya diciptakan melalui bahasa dan budaya bersama dari interpretasi subjektif individu, atas orang-orang yang mereka anggap penting yang punya hubungan dekat (significant others). Demikian pula pengambilan peran dan sikap orang lain secara umum (generalized others). Jadi, kesimpulan Cooley tentang "diri" bahwa individu dan masyarakat bukanlah realitas yang terpisah.

\section{3 "Diri” ala Pemikiran William James ${ }^{10}$}

William James menjelaskan "Diri” tidak jauh berbeda dengan argumentasi Mead bahwa konsep "diri"(self) dapat bersifat sebagai objek maupun subjek sekaligus. Objek yang dimaksud berlaku pada dirinya sendiri sebagai karakter dasar dari makhluk lain, sehingga mampu mencapai kesadaran diri (self conciousness), dan dasar mengambil sikap untuk dirinya juga untuk situasi sosial. James mengakui bahwa individu mempunyai banyak "diri" sebanyak kelompok berlainan yang merespon individu tersebut. Prinsipnya bahwa "diri" merefleksikan masyarakat, memerlukan suatu pandangan atas 'diri” sesuai dengan realitas. William James menyimpulkan bahwa tidak ada realitas tunggal, melainkan realitas yang tak terbatas, seperti realitas kehidupan sehari-hari, mimpi, sains termasuk realitas pribadi.

\subsection{Howard S. Becker dan Teori "labelling"11}

Howard S. Becker mengklaim bahwa kelompok sosial menciptakan penyimpangan (deviance) dengan pembuatan aturan mendasar dengan menerapkan aturan itu kepada orang-orang tertentu dan memberikan label mereka sebagai orang luar. Menurut Becker, setelah individu berlabel menyimpang, mereka akan terus menyimpang dan menjadi sulit untuk melepaskan label tersebut, karena orang lain melihatnya dengan status individu menunjuk orang luar (Outsiders). Studi Sociology of Deviance menunjukan bahwa ketika mempelajari orang penyimpang, seseorang tidak harus menerima penyimpangan mereka sebagaimana adanya karena seseorang menganggap orang-orang tersebut benar telah melakukan tindakan penyimpangan atau melanggar beberapa aturan, karena proses teori penjulukan tidak sempurna. Penjulukan penyimpang tidak perlu berarti bahwa individu telah melakukan penyimpangan di masa lalu.

Backer menguatkan bahwa penyimpangan bukanlah suatu properti yang melekat pada bentuk tingkah laku tertentu, tetapi properti yang digunakan oleh individu. Penyimpangan menurut teori penjulukan oleh Becker, diperlukan pada stabilitas masyarakat dibandingkan tanggung jawab pada kerusakannya. Karena individu yang menyimpang bertindak sebagai parameter perbedaan antara baik dan buruk, benar dan salah.

\section{5 "Transformasi Identitas" Anselm Strauss}

Mulyana (2006 : 231) menyebutkan bahwa transformasi identitas mengisyaratkan penilain baru tentang diri pribadi dan orang lain, tentang peristiwa, tindakan, dan objek. Menurut perspektif teori interaksi simbolik, transformasi identitas menyangkut perubahan psikologi. Perubahan ini dapat diidentifikasikan melalui pelakunya yang menjadi berbeda dari sebelumnya. Strauss mengakui melalui transformasi persepsi seseorang bersifat irreversible, artinya sekali berubah tidak bisa kembali lagi.

\subsection{Norman Denzin ${ }^{12}$}

Norman Denzin (1987) melihat proses transformasi identitas dalam pendekatan teori interaksi simbolik, bertumpu pada upaya membangun konsep diri dan relasi-relasi sosialnya. Menurut Denzin, transformasi identitas adalah proses di mana seseorang secara aktif memeroleh citra diri yang baru, bahasa diri yang baru, hubungan-hubungan baru, dengan orang lain, dan ikatan-ikatan baru dengan tatanan sosial.

Hal lain yang dijelaskan Denzin, individu- 
Terakreditasi Dirjen Dikti SK No. 56/DIKTI/Kep/2005

individu yang terlibat dalam interaksi tersebut tidak selamanya berjalan mulus, meski berasal dari budaya yang sama, karena menggunakan simbol yang tidak signifikan - simbol yang tidak bermakna bagi pihak lain. Akibatnya, orang tersebut harus terus menerus mencocokkan makna dan merencanakan cara tindakan mereka. Jika dikaitkan dengan metodologi, maka seperti yang telah disinggung sebelumnya, interaksi simbolik termasuk salah satu dari sejumlah tradisi penelitian kualitatif yang berasumsi bahwa penelitian sistematik harus dilakukan dalam suatu lingkungan yang alamiah, atau lingkungan yang artifisial seperti eksperimen.

Lebih jauh, Denzin (dalam Mulyana, 2006) mengemukakan tujuh prinsip metodologis berdasarkan teori interaksi simbolik, di antaranya: (1) Simbol dan interaksi harus dipadukan sebelum penelitian tuntas; (2) Peneliti harus mengambil perspektif atau peran orang lain yang bertindak (the acting other) dan memandang dunia dari sudut pandang subjek; (3) Peneliti harus mengaitkan simbol dan defenisi subjek dengan hubungan sosial dan kelompok yang memberikan konsepsi demikian; (4) Setting perilaku dalam interaksi tersebut dan pengamatan ilmiah harus dicatat; (5) Metode penelitian harus mampu mencerminkan proses atau perubahan, juga bentuk perilaku yang statis; (6) Pelaksanaan penelitian paling baik dipandang sebagai suatu tindakan interaksi simbolik; (7) Penggunaan konsep yang layak dimulai dari mengarahkan (sensitizing) dan kemudian operasional; teori yang layak menjadi teori formal, bukan teori agung (grand theory) atau teori menengah (middle-range theory): dan proposisi yang dibangun menjadi interaksional dan universal.

Upaya Denzin tersebut, sejalan dengan pandangan Glaser dan Strauss untuk membangun teori berdasarkan data (grounded theory) dan dianggap sebagai salah satu upaya serius untuk mengembangkan metodologi Interaksi Simbolik sebagai suatu perspektif teoretis, sekaligus berorientasi metodologis.

\subsection{Aoron Cicourel}

Cicourel lebih banyak membangun argumennya pada wilayah metodologi dengan perspektif penelitian interaksi simbolik yang bersifat kualitatif. Ia menegaskan bagaimana sebuah logika yang murni matematis dapat mengabaikan pemikiran akal sehat (common-sense reasoning), yang digunakan oleh orang yang diteliti dan peneliti. Menurutnya, manusia tidak eksis jika terlepas dari motif dan tujuannya. Bahwa interaksi simbolik merupakan perspektif teoretis, sekaligus berorientasi metodologis. Hal ini juga dipertegas kembali oleh pendapat Silverman, MacIver, dan Geertz bahwa perhatian interaksi simbolik pada aspek fenomenologis perilaku manusia yang mempunyai implikasi metodologis, sehingga bagi Cicourel, penelitian kualitatif, khususnya interaksi simbolik, lebih menekankan pada aspek bahasa dan makna subjek penelitian. Cicourel berpendapat, makna cultural mengenai kehidupan akhirat, kausal, peristiwa fisik, sosial, peristiwa biologis, dan sebagainya, memiliki tata bahasa yang dipengaruhi bahasa. Kesimpulan mereka tentang penelitian kualitatif mengandalkan otentitas dan pemahaman yang mendalam tentang permasalahan penelitian. Dengan demikian, penelitian kualitatifberdasarkan perspektif interaksi simbolik yang bersifat induktif.

\subsection{Jack Douglas ${ }^{13}$}

Hampir sama dengan pemikiran dan analisis Cicourel, Douglas dalam bukunya The Social Meaning of Sucide (Mulyana, 2006) juga mengurai panduan metodologi penelitian dalam perspektif interaksi simbolik, dengan memfokuskan perhatiannya pada makna sosial. Salah satu penelitian yang dilakukan Douglas tentang makna sosial bunuh diri menggunakan catatan harian sebagai sumber data. Walaupun cara ini ditentang oleh Denzin, akhirnya membantu Douglas merumuskan temanya menjadi informasi penting.

\subsection{Pemikiran Herbert Blumer}

Dalam penjelasan konsepnya tentang interaksi simbolik, Blumer menunjuk kepada sifat khas dari tindakan atau interaksi antarmanusia. 
Kekhasannya bahwa manusia saling menerjemahkan, mendefenisikan tindakannya, bukan hanya reaksi dari tindakan seseorang terhadap orang lain. Tanggapan seseorang, tidak dibuat secara langsung atas tindakan itu, tetapi didasarkan atas "makna" yang diberikan. Olehnya, interaksi dijembatani oleh penggunaan simbol, penafsiran, dan penemuan makna tindakan orang lain. Dalam konteks ini, menurut Blumer, actor akan memilih, memeriksa, berpikir, mengelompokkan, dan mentransformasikan makna sesuai situasi dan kecenderungan tindakannya, (Basrowi dan Sukidin, 2002). Pada bagian lain, Blumer dalam Soeprapto (2002) mengatakan bahwa individu bukan dikelilingi oleh lingkungan objek-objek potensial yang mempermainkan dan membentuk perilakunya, sebaliknya ia membentuk objek-objek itu. Dengan begitu, manusia merupakan actor yang sadar dan reflektif, yang menyatukan objek yang diketahuinya melalui apa yang disebutnya sebagai self-indication. Maksudnya, proses komunikasi yang sedang berjalan dimana individu mengetahui sesuatu, menilainya, memberi makna dan memberi tindakan dalam konteks sosial. Menurutnya dalam teori interaksi simbolik mempelajari suatu masyarakat disebut "tindakan bersama".

Dalam perspektif Blumer, teori interaksi simbolik mengandung beberapa ide dasar, yaitu:

(1) Masyarakat terdiri atas manusia yang bertinteraksi. Kegiatan tersebut saling bersesuaian melalui tindakan bersama, membentuk struktur sosial;

(2) Interaksi terdiri atas berbagai kegiatan manusia yang berhubungan dengan kegiatan manusia lain. Interaksi nonsimbolis mencakup stimulus respons, sedangkan interaksi simbolis mencakup penafsiran tindakan-tindakan;

(3) Objek-objek tidak memiliki makna yang intrinsik. Makna lebih merupakan produk interaksi simbolis. Objek-objek tersebut dapat diklasifikasikan ke dalam tiga kategori, yaitu objek fisik, objek sosial, dan objek abstrak;

(4) Manusia tidak hanya mengenal objek eksternal. Mereka juga melihat dirinya sebagai objek;
(5) Tindakan manusia adalah tindakan interpretasi yang dibuat manusia itu sendiri;

(6) Tindakan tersebut saling berkaitan dan disesuaikan oleh anggota-anggota kelompok. Ini merupakan "tindakan bersama". Sebagian besar "tindakan bersama" tersebut dilakukan berulang-ulang, namun dalam kondisi yang stabil. Kemudian di saat lain ia melahirkan kebudayaan. (Bachtiar, 2006:249-250).

Kesimpulan Blumer bertumpu pada tiga premis utama, yaitu: (1) manusia bertindak berdasarkan makna-makna yang ada pada sesuatu bagi mereka; (2) makna itu diperoleh dari hasil interaksi sosial yang dilakukan dengan orang lain; (3) maknamakna tersebut disempurnakan di saat proses interaksi sosial sedang berlangsung (Soeprapto, 2002:123-124)

Sebagai salah satu pemikir dan pengembang teori interaksi simbolik, membuat gagasanya cenderung kritis terhadap alam. Kritikannya yang cukup popular dikalangan penganut teori interaksionis yakni "analisis variabel" ala ilmu alam. Metodologi yang dibangun Blumer menolak anggapan analisis variabel bisa diterapkan dalam perilaku manusia. Penelitian yang bertumpu pada tindakan dan perilaku manusia menekankan kebutuhan untuk secara jelas (insightful), dan utuh. Keberatan Blumer atas analisis variabel berakar pada kenyataan bahwa argumentasi ilmiah ilmu alam pada umumnya palsu. Hal-hal yang diindentifikasi, tidak jelas dan bukan objek terpisah dengan susunan utuh sebagaimana yang dimiliki variabel sejati, melainkan istilah-istilah rujukan yang disingkat bagi pola-pola rumit. Selanjutnya, Blumer menguraikan bahwa apa yang disebut variabel sosial itu tidak dapat kita uraikan dengan cara ini. Sementara, apa yang disebut veriabel generik yang tampak seperti: usia, jenis, tingkat kelahiran, dan periode waktu, masih harus dipertanyakan. Dalam pandangan Blumer, untuk menelaah kehidupan sosial, sepantasnya menggunakan pendekatan naturalistik, bukan veriabel ala ilmu alam. Menurut Blumer lagi, dalam penerapan variabel-variabel tersebut juga tidak universal dan lazimnya kekurangan indikator yang tetap atau seragam. 


\section{Fokus dan Perspektif Interaksi Simbolik}

Manusia pada hakikatnya adalah makhluk yang berinteraksi. Bahkan, interaksi itu tidak hanya ekslusif antarmanusia, melainkan inklusif dengan seluruh mikrokosmos, termasuk interaksi manusia dengan seluruh alam ciptaan. Singkatnya, manusia selalu mengadakan interaksi. Setiap interaksi mutlak membutuhkan sarana tertentu. Sarana menjadi medium simbolisasi dari apa yang dimaksudkan dalam sebuah interaksi.

Teori interaksi simbolik dipengaruhi oleh struktur sosial yang membentuk atau menyebabkan perilaku tertentu, yang kemudian membentuk simbolisasi dalam interaksi sosial masyarakat. Teori interaksi simbolik menuntut setiap individu mesti proaktif, refleksif, dan kreatif, menafsirkan, menampilkan perilaku yang unik, rumit, dan sulit diinterpretasikan. Teori interaksi simbolik menekankan dua hal. Pertama, manusia dalam masyarakat tidak pernah lepas dari interaksi sosial. Kedua, interaksi dalam masyarakat mewujud dalam simbol-simbol tertentu yang sifatnya cenderung dinamis.

Menurut Fisher, interaksi simbolik adalah teori yang melihat realitas sosial yang diciptakan manusia. Sedangkan manusia sendiri mempunyai kemampuan untuk berinteraksi secara simbolik, memiliki esensi kebudayaan, saling berhubungan, bermasyarakat, dan memiliki buah pikiran. Setiap bentuk interaksi sosial dimulai dan berakhir dengan mempertimbangkan diri manusia (Fisher, 1986: 231).

Pada dasarnya, teori interaksi simbolik ini berakar dan berfokus pada hakikat manusia sebagai makhluk relasional. Setiap individu pasti terlibat relasi dengan sesamanya. Maka, tidaklah mengherankan bila kemudian teori interaksi simbolik lebih banyak digunakan bila dibandingkan dengan teori-teori sosial lainnya. Salah satu alasannya adalah bahwa diri manusia muncul dalam dan melalui interaksi dengan yang di luar dirinya. Interaksi itu sendiri membutuhkan simbol-simbol tertentu. Simbol itu biasanya disepakati bersama dalam skala kecil maupun skala besar. Simbol-misalnya bahasa, tulisan dan simbol lainnya yang dipakai-bersifat dinamis dan unik. Keunikan dan dinamika simbol dalam proses interaksi sosial menuntut manusia harus lebih kritis, peka, aktif, dan kreatif dalam menginterpretasikan simbol-simbol yang muncul dalam interaksi sosial. Penafsiran yang tepat atas simbol tersebut turut menentukan arah perkembangan manusia dan lingkungan. Faktorfaktor penting keterbukaan individu dalam mengungkapkan diri-nya merupakan hal yang tidak dapat diabaikan dalam interaksi simbolik. Hal-hal lainnya yang juga perlu diperhatikan adalah pemakaian simbol yang baik dan benar, sehingga tidak menimbulkan kerancuan interpretasi. Setiap subjek mesti memperlakukan individu lainnya sebagai subjek, bukan objek. Segala bentuk apriori mesti dihindari dalam menginterpretasikan simbol yang ada agar unsur subjektif dapat diminimalisir sejauh mungkin. Pada akhirnya, interaksi melalui simbol yang baik, benar, dan dipahami secara utuh, akan membidani lahirnya berbagai kebaikan dalam hidup manusia.

Joel M. Charon (1979) mendefinisikan interaksi sebagai aksi sosial bersama, individu individu berkomunikasi satu sama lain mengenai apa yang mereka lakukan dengan mengorientasikan kegiatannya kepada dirinya masing masing" ( $m u$ tual social action, individuals, communicating to each other in what they do, orienting their acts to each others).

Jarome Manis dan Bernard Meltzer dalam Littlejhon (2004) mengemukakan tujuh proposisi dasar dalam interaksi simbolik, yakni: (1) Manusia memahami sesuatu melalui makna yang diperoleh dari pengalaman, persepsi manusia selalu mencul menggunakan simbol-simbol; (2) Makna dipelajari melalui interaksi antar manusia dan makna muncul dari pertukaran simbol dalam kelompok sosial; (3) Semua struktur dan institusi sosial dibuat berdasarkan interaksi antar manusia; (4) Perilaku manusia tidak hanya dipengaruhi oleh kejadian, melainkan oleh kehendak dirinya sendiri; (5) Benak manusia berisi percakapan bersifat internal, yang merefleksikan bahwa dia telah berinteraksi; (6) Perilaku tercipta dalam interaksi dengan kelompok sosial; (7) Seseorang tidak dapat dipahami hanya 
dari perilaku yang terbuka.

Jika Mazhab Iowa yang dikembangkan oleh Marford H. Kuhn dalam kajiannya menggunakan metode sainstifik (positivistik) untuk menemukan hukum-hukum universal mengenai perilaku sosial yang dapat diuji secara empiris, maka Mazahab Chicago yang dikembangkan oleh Mead, Blumer, Gofmann, dan interpretis lainnya, menggunakan pendekatan humanistik. Walaupun Kuhn tidak menolak sama sekali studi tentang aspek-aspek tersembunyi mengenai perilaku manusia ia menyarankan penggunaan instrumen objektif untuk mengukur perilaku terbuka, guna mengukur gagasan-gagasan Mead.

Perspektif Interaksi Simbolik berusaha memahami perilaku manusia dari sudut pandang subjek. Perspektif ini menyarankan bahwa perilaku manusia harus dilihat sebagai proses yang memungkinkan manusia membentuk dan mengatur perilaku mereka dengan mempertimbangkan ekspetasi orang lain yang menjadi mitra interaksi mereka. Demikian menurut Howard S. Becker (dalam Mulyana, 2006:70). Manusia bertindak hanya berdasarkan definisi atau penafsiran mereka atas objek-objek di sekeliling mereka. Demikian pula masyarakat, dalam pandangan penganut interaksi simbolik, adalah proses interaksi simbolik. Dan pandangan ini memungkinkan mereka untuk menghindari problem-problem strukturalisme dan idealisme dan mengemudikan jalan tengah di antara kedua pandangan tersebut. Kehidupan sosial pada dasarnya adalah interaksi manusia dengan menggunakan simbol-simbol. Penganut Interaksi Simbolik berpandangan, perilaku manusia pada dasarnya adalah produk dari interpretasi mereka atas dunia di sekeliling mereka. Artinya, mereka tidak mengakui bahwa perilaku itu dipelajari atau ditentukan, tetapi dipilih sebagai hal yang layak dilakukan berdasarkan cara individu mendefinisikan situasi yang ada. (Hall, dalam Mulyana, 2006). Hal ini dipertegas George Simmel bahwa teori ini berawal dari asumsi-asumsi sosiopsikologis, "semua fenomena dan atau perilaku sosial itu bermula dari apa yang ada dalam alam pikiran individu" (Soeprapto, 2002).

Dengan demikian, mengutip pendapat Blumer secara ringkas premis-premis yang mendasari interaksi simbolik, di antaranya: pertama, individu merespon suatu situasi simbolik. Seperti lingkungan, objek fisik (benda), dan objek sosial (perilaku manusia) berdasarkan makna yang dikandung komponen-komponen lingkungan tersebut bagi mereka. Kedua, makna adalah produk interaksi sosial, karena itu makna tidak melekat pada objek, melainkan dinegosiasikan melalui penggunaan bahasa. Ketiga, makna yang diinterpretasikan individu dapat berubah dari waktu ke waktu, sejalan dengan perubahan situasi yang ditemukan dalam interaksi sosial. Di dalam interaksi simbolik, maka akan selalu berhubungan dengan teori diri dari Mead, karena teori ini merupakan inti dari interaksi simbolik.

Esensi dari teori interaksi simbolik menurut Mulyana (2006) adalah suatu aktivitas yang merupakan ciri khas manusia, yakni komunikasi atau pertukaran simbol-simbol yang diberi makna. Bahwa individu dapat ditelaah dan dianalisis melalui interaksinya dengan individu yang lain. Dengan demikian, teori ini menggunakan paradigma individu sebagai subjek utama dalam realitas sosial.

\section{Penelitian Interaksi Simbolik}

Dalam penelitian mengenai iklan dan prostitusi, subjek menggunakan 'iklan panti pijat' sebagai media (simbol) penawaran jasa prostitutisinya. Subjek yang lain memanfaatkan 'tampil di cover majalah pria' sebagai media lain penawaran atau komunikasi pemasaran jasa prostitutisinya. Subjek yang lain lagi, 'menjual diri' dengan tampil di situs jejaring sosial Face Book (FB) dengan foto-foto yang 'mengundang' sebagai media komunikasi pemasaran atau iklan jasa prostitutisinya. Bagaimana subjek membentuk simbol-simbol pengiklanan diri tersebut. Bagaimana pelanggan dapat menangkap makna simbol-simbol tersebut sehingga terjadi interaksi dan transaksi 'gelap' dengan menggunakan simbol-simbol eksklusif lain? Bagaimana subjek memandang dan mendefinisikan diri mereka berdasarkan pandangan orang lain? Apakah mereka lebih senang disebut pelacur, pelacur kelas atas, escort, pemijat plus, 
model plus, atau sekadar 'teman jalan'? Adakah istilah-istilah dan bahasa-bahasa isyarat tertentu yang mereka gunakan? Bagaimana dengan keluarga dan teman-teman mereka di luar lingkungan prostitutif mereka? Apakah mereka menyembunyikan profesi mereka atau terbuka? Berapa banyak pelanggan dan penghasilan mereka dari hasil beriklan? Adakah pengaruh iklan terhadap kenaikan penghasilan mereka? Digunakan untuk apa saja penghasilan mereka? Lebih banyak untuk membantu perekonomian diri dan keluarga, atau lebih banyak untuk bersenang-senang? Bagaimana pula pengaruh Media $F B$ yang digunakannya. ${ }^{14}$

\section{Penutup}

Interaksi simbolik dalam ilmu sosial, khususnya komunikasi, merupakan teori dasar, dan variannya mencakup berbagai teori, di antaranya: labelling theory, teori transformasi identitas. Teori tersebut dapat digunakan dalam menganalisis gejala masyarakat, karena berakar dan berfokus pada hakikat manusia sebagai makhluk relasional. Interaksi itu sendiri membutuhkan simbol-simbol tertentu. Keunikan dan dinamika simbol dalam proses interaksi sosial menuntut manusia harus lebih kritis, peka, aktif, dan kreatif dalam menginterpretasikan simbol yang muncul dalam interaksi sosial. Jadi, Teori ini memberikan pandangan yang menonjolkan mengenai perilaku komunikasi antarmanusia dalam konteks yang sangat luas dan bervariasi. Teori ini dikembangkan dengan baik, mulai dari peranan diri dan kemudian berkembang pada penelitian mengenai diri dalam masyarakat.

Beberapa kritikan terhadap interaksionalisme simbolis karena beberapa hal, di antaranya: terlalu abstraksi yang spekulatif, dianggap sebagai filsafat sosial daripada teori sosial. Selain itu, konsep dalam Interaksi Simbolik digunakan dengan batasan yang kurang jelas, misalnya diri, aku, aku dan peran. Teori ini pula dianggap gagal menghubungkan konsep makna dengan diri.
Tetapi, pada akhirnya penafsiran yang tepat atas simbol tersebut turut menentukan arah perkembangan manusia dan lingkungan. Sebaliknya, penafsiran yang keliru atas simbol dapat menjadi musibah bagi manusia dan lingkungannya. Keterbukaan individu dalam mengungkapkan dirinya merupakan hal yang tidak dapat diabaikan dalam interaksi simbolik. Hal-hal lainnya yang harus diperhatikan adalah pemakaian simbol yang baik dan benar, sehingga tidak menimbulkan kerancuan interpretasi.

\section{Catatan Akhir}

http://www.colorado.edu/Communication/meta-discourses/Papers/App_Papers/Nelson.htm

2 http://books.google.co.id/books?id=YisaULoW5 UC\&pg=PA131\&lpg=PA131\&dq=\%22Manford+Kuhn $\%$ $22 \& \mathrm{source}=\mathrm{b} 1 \&$ ot $\mathrm{s}=\mathrm{mg} \mathrm{O}$ o T f P T R \& s ig $=92 \mathrm{~b} \mathrm{~S} \mathrm{~W} 18 \mathrm{p} \mathrm{v} \mathrm{z} \mathrm{U} \mathrm{q} 1 \mathrm{~m} \mathrm{Q} \mathrm{C} \mathrm{S} \mathrm{J} \mathrm{W} \mathrm{Y} \mathrm{S} \mathrm{w} \mathrm{e} \mathrm{-}$ $\mathrm{J} 9 \mathrm{I} \& \mathrm{hl}=\mathrm{id} \& \mathrm{sa}=\mathrm{X} \&$ oi $=$ book_result $\&$ resnum $=2 \& \mathrm{ct}=$ result

3 Makyun Subuki, 15 November 2006, Komunikasi dalam Teori Interaksionisme Simbolis, Strukturasi, dan Konvergensi, http://tulisanmakyun.blogspot.com/ 2008/02/teori-komunikasi_29.html.

4 http://en.wikipedia.org/wiki/George_Ritzer

5 Miller Katherine, p 55

6 http://socio.ch/sim/bio.htm

8 http://www.sociologyprofessor.com/socialtheorists/ georgeherbertmead.php10 http://media.pfeiffer.edu/ lridener/courses/LKGLSSLF.HTML

9 Nelson. D. Lindsey. Herbert Blumer's Symbolic Interactionism. University of Colorado at Boulder Spring 1998. http://www.colorado.edu/Communication/meta-discourses/Papers/App_Papers/Nelson.htm

10 http://psychclassics.yorku.ca/James/Principles/ prin $10 . \mathrm{htm}$.

11 www.hewett.norfolk.sch..uk/curric/soc/crime/ labeling.htm

12 http://sobek.colorado.edu/SOC/SI/si-denzin.htm

13 http://www.guardian.co.uk/film/2008/dec/19/1

14 http://bambangsukmawijaya.wordpress.com/2007/12/ 07/fenomenologi-dan-interaksi-simbolik/ 


\section{Daftar Pustaka}

Bachtiar, Wardi. 2006. Sosiologi Klasik. Bandung: Remaja Rosdakarya

Basrowi dan Sukidin. 2002. Metode Penelitian Kualitatif Perspektif Mikro. Surabaya: Insan Cendekia

Becker, Howard. 1963. Overview of Labelling Theories, www. Hewett, Norfolk. Sch.uk/curric/ soc/crime/labelling/ diakses pada 10 Agustus 2008.

Charon, Joel M. 1979. Symbolic Interactionism, United States of America: Prentice Hall Inc

Fisher, B. Aubrey. 1986. Teori-teori Komunikasi. Perspektif Mekanistis, Psikologis, Interaksional, dan Pragmatis. Penterjemah Soejono Trimo, Penyunting Jalaluddin Rakhmat. Bandung: Remaja Rosdakarya.

Francis M. Abraham. 1982 Modern Sociological Theory (An Introduction). Oxford: Oxford University Press. Chapter 8. Simbolic Interacsionism.

Goffman, Erving, 1959. The Presentation of Self in Everyday Life, London: Harmondsworth, Penguin

Griffin, Emory A. 2004. A First Look At Communication Theory. New York: McGraw-Hill.

Horton, Paul B dan Chester L. Hunt. 1984. Sociology. Jakarta: Penerbit Erlangga.

Littlejohn, Stephen, W. 2004. Theories of Human Communication. New York, USA: Artists Right Society (ARS).

Theories of Human Communication (edisi ketujuh). Belmont: Thomson Learning. Hal. 144-162

Mulyana, Deddy. 2006. Metodologi Penelitian Kualitatif, Paradigma Baru Ilmu Komunikasi dan Ilmu Sosial Lainnya. Bandung: Remaja Rosdakarya.

1999. Nuansa-Nuansa
Komunikasi, Meneropong Politik dan

Budaya Komunikasi Masyarakat Kontemporer. Bandung: Remaja Rosdakarya.

2000. Ilmu Komunikasi:

Suatu Pengantar, Bandung: Remadja Rosdakarya.

Mulyana, Deddy dan Rakhmat, Jalaluddin, 1998. Komunikasi Antarbudaya, Bandung: Remadja Rosdakarya.

Miller, Katherine, 2005. Communication Theories, Perspectives, Process, and Contexts, Second Edition, Singapore: McGraw-Hill International Edition Rosdakarya.

Moleong, Lexy J, 2000. Metodologi Penelitian Kualitatif, Bandung: Remaja Rosdakarya.

Nelson. D. Lindsey. 1998. Herbert Blumer's Symbolic Interactionism. University of Colorado at Boulder Spring. http://www.colorado.edu/ Communication /metadiscourses/Papers/ App_Papers/Nelson.htm diakses pada 05 Januari 2009 pkl. 09.00

Rahmat, Jalaluddin. 1995. Metode Penelitian Komunikasi, Bandung: Remadja Rosdakarya

Rahim, A. Samsudin. 2006. Kumpulan Esei Isu-Isu Komunikasi. Kuala Lumpur, Malaysia: Ampang Press Sdn Berhad.

Soeprapto, Riyadi. 2002. Interaksi Simbolik, Perspektif Sosiologi Modern. Yogyakarta: Averrpes Press dan Pustaka Pelajar.

Uchjana, Onong E. 2003. Ilmu, Teori dan Filsafat Komunikasi. Bandung: PT Citra Aditya Bakti.

Veeger. KJ . 1993. Realitas Sosial, Refleksi Filsafat Sosial atas Hubungan Individu Masyarakat dalam Cakrawala Sejarah Sosiologi. Jakarta: Gramedia. Hlm 224-226.

Wood, JT. 2000. Communication Theories in Action. Calofornia: Belmont

West. Richard dan Turner.H.Lynn. 2008. Pengantar Teori Komunikasi, Analisis dan Aplikasi. Jakarta: Salemba Humanika 
Terakreditasi Dirjen Dikti SK No. 56/DIKTI/Kep/2005

\section{Sumber lainnya:}

Makyun Subuki, 15 November 2006, Komunikasi dalam Teori Interaksionisme Simbolis, Strukturasi, dan Konvergensi http:// tulisanmakyun.blogspot.com /2008/02/ teori-komunikasi_29.html

http://bambangsukmawijaya.wordpress.com/ 2007/12/07/fenomenologi-dan-interaksisimbolik/diakses pada 25 Desember 2008 pkl. 08.10

http://teorikomunikasi-umy.blogspot.com/2005/ 0 9/t e ori-tentang-interaksisimbolik_13.html, diakses pada 25 Desember 2008 pkl. 08.10

http://www.pontianakpost.com/berita/ index.asp? Berita $=$ Opini\&id $=95576$, diakses pada 28 Desember, 12.00 http://averroes.or.id/2007/12/12/teoriinteraksionisme-simbolik/ diakses pada 28 Desember, 12.00

http://fisip.untirta.ac.id/teguh/?p=17 diakses pada 28 Desember, 12.00

http://jejakelana.blog.com/355151/ diakses pada 28 Desember, 12.00

http://sobek.colorado.edu/SOC/SI/sitableofcontents.htm

The Society for More Creative Speech. (1996). Symbolic Interactionism as Defined by Herbert Blumer. http://www.thepoint.net/-usul/text/ blumer.html

http://www.colorado.edu/Communication/ meta_discourses/Papers/App_Papers/ Nelson.htm 
